\title{
INNOVATIVE INTESTIFICATION OF TESTING OF STRENGTH ENDURANCE IN PHYSICAL EDUCATION OF STUDENTS WITH CHRONIC DISEASES
}

\author{
Koryahin V.M., Blavt O.S., Ponomaryov S.V. \\ National University "Lviv Polytechnic" \\ Corresponding Author: Blavt O., e-mail: oksanablavt@ukr.net \\ Accepted for Publication: September 20, 2019 \\ Published: September 25, 2019
}

DOI:10.17309/tmfv.2019.3.02

\begin{abstract}
The study objective is to substantiate and implement modern information-communication technologies (ICT) means for improving the testing of strength endurance of hands and upper body of students with chronic diseases in physical education.

Materials and methods. To solve the research tasks used the methods of comparing and contrasting are used and analysis, synthesis, abstraction, formalization and technical modelling.

Results. The result of a scientific search aimed at integrating ICT into test control of strength endurance of students with chronic diseases is a device of capacitive sensor testing. The designed capacitive touch tester is based on a combination of modern nanotechnology and microprocessor systems, including smart phone's, tablets, etc. It is a constructive solution for electronic measuring systems of spatial position of objects based on capacitive sensor devices.

Conclusions. The effectiveness of using the designed device in testing students' of strength endurance of hands and upper body is achieved through the ease of use and compactness of the device, student-friendly testing procedure and the efficiency and reliability of control.
\end{abstract}

Key words: testing, control, student, chronic diseases, ICT, capacitive touch device, control.

\section{Introduction}

Problem statement. Ensuring the implementation of the wellness function of physical education of students with chronic diseases of universities requires a comprehensive study of indicators characterizing the state of various aspects of physical fitness and the availability of a reliable information control system (Anikieiev, 2015). Test control in our context of physical development and physical fitness of students with disabilities is a methodological basis for managing the physical education system of universities (Koryahin \& Blavt, 2016). Today, the issues of testing the level of physical fitness of students and predicting their functionality are some of the most relevant in the theory and methodology of physical education.

The need and importance of finding innovative approaches to optimize test controls and improve the technological foundations of this process is dictated by time. Scientific and technological progress in the field of physical education has recently become a reality that cannot be ignored (Sukhova, 2009; Kachan, 2017). The

(C) Koryahin V.M., Blavt O.S., Ponomaryov S.V., 2019. relevance of our research is determined by the decisive importance for the effective physical education of students of students with chronic diseases methods of forming a comprehensive control system on the one hand and the lack of its scientific substantiation and technological support on the other. It is considered that one of the promising directions of improving the system of physical education of students with chronic diseases in the state of health of universities is the development and practical implementation of new highperformance technologies of test control (Stroot, 2014; Overton, Wrench, A. \& Garrett, 2016).

Analysis of recent research and publications. Physical fitness is an important result of the physical education of students with chronic diseases was proved (Bassett, 2000). Numerous authors (Iedynak, Galamandjuk, Ivashchenko, Stasjuk, Guska, Prozar, Mazur, \& Sliusarchuk, 2017; Reiman\& Manske, 2009) have emphasized that its level is an integral indicator of the state and level of health. One of the important components of the physical fitness of students with chronic diseases is the level of endurance (Koryagin, Blavt, \& Tsiovkh, 2018). Strength is attributed to specific types of power. It reflects the ability to perform power work for a long time 
without reducing its effectiveness. In fact, it is the ability to withstand fatigue caused by prolonged muscle stress of considerable magnitude (Matiegka, 1991).

An effective way of testing the endurance of the arms and upper torso, according to which the test process is monitored, is to perform an exercise «Body retention on the crossbar», which fixes the retention time according to generally accepted standards (Koryagin, \& Blavt, 2019). The methodological feature of the test is that the chin should be over the bar and not touch it, that is, the body should occupy a practically stable position. However, in this way there is a certain dependence of the subjective assessment of the perception of the teacher conducting this testing, the observance of the required position of the body and hands, which are set visually during the monitoring. There is a likelihood of error in setting the retention time of the required posture, which makes it impossible and difficult to obtain reliable assessment results, respectively, they cannot testify to the effectiveness of the educational process used.

Based on the summarized relevant literature sources on this issue (Bassett, 2000; Ivashchenko, 2016; Magill, 2007), it is determined that the effectiveness of test methods level of physical fitness is determined by the following characteristics: they must be reasonable, reliable and informative, and their conduct requires clear control.

However, the current methodology makes it impossible to obtain reliable indicators due to the large number of uncontrolled variables and the lack of continuous recording of test results. In the special literature available to us (Kachan, 2017; Reiman, Manske, 2009), the authors agree that it is practically impossible to carry out a test in an exercise to determine the level of strength endurance of the hands and upper body of a specialist in physical education, unlike other test requirements with clear standardization of testing procedures and objective measurement using a stopwatch, roulette, etc. The analysis of the test revealed the existing contradictions between the need to ensure the objectivity of testing and the lack of ability to do so. Therefore, there is a need for a fundamentally new approach to addressing this issue.

It was the search for ways to improve the method of determining the level of strength endurance of the hands and upper torso, and determined the choice of topic and direction of study. An analysis of the available publications on this issue (Haake, 1996; Morze, Kocharian, 2014; Prykhodko, 2010) indicates that the solution to this problem is related to the use of modern technologies for obtaining objective information. The technological basis of this issue in the physical education of students with health disabilities needs scientific refinement, which is recognized by scientists. To date, the proposed automated monitoring approach has not been used in the science of physical education of students with chronic diseases. In this regard, it is important to consider further study of the effectiveness of automated methods of testing the strength endurance of the hands and upper torso in the context of modern electronic devices (Kachan, 2017; Koryahin, Mukan, Blavt \& Virt, 2019; Shyrobokov, Malinina, \& Malinin, 2012).

Purpose of the research is to substantiate and implement modern information-communication technologies (ICT) means for improving the testing of strength endurance of hands and upper body of students with chronic diseases in the physical education.

\section{Materials and methods}

To solve the research tasks used the methods of comparing and contrasting are used and analysis, synthesis, abstraction, formalization and technical modeling. The research strategy is focused on the integration of the information resource of ICT to ensure the effectiveness of control.

\section{Results}

In this respect, it is of interest to develop new ICT based on the introduction of computerization of the test process in the physical education of students with chronic diseases of universities (Koryahin \& Blavt, 2016; Shyrobokov, Malinina \& Malinin, 2012; Hotra, Holyaka, Marusenkova, \& Potencki, 2010).

In order to carry out an objective evaluation and to provide reliable results of monitoring the strength endurance of the hands and upper torso, we have developed a capacitive touch test device. The device includes: two electrodes, a signal line, a signal converter, an interface, a communication line, and an electronic computing device or mobile communication system, in particular, a smartphone or a tablet computer (Fig. 1).

The designed capacitive touch tester is based on a combination of modern nanotechnology and microprocessor systems, including smartphones, tablets, and more. It is a constructive solution for electronic measuring systems of spatial position of objects based on capacitive sensor devices (Bracke, Puers \& Van Hoof, 2007).

The information signal of capacitive sensors is the electrical capacitance between the electrodes, which changes under the influence of external factors. The informative parameter of the dynamics of the exercises is determined by the time dependence of the distance of the body from the capacitive electrodes, which is determined by the measurement of interelectrode capacities. As the monitoring subject approaches, these capacities increase and, at removal, decrease. A significant advantage of capacitive type sensors is the contactlessness of the measurement process, which ensures their high ergonomics (Baxter, 1997). 


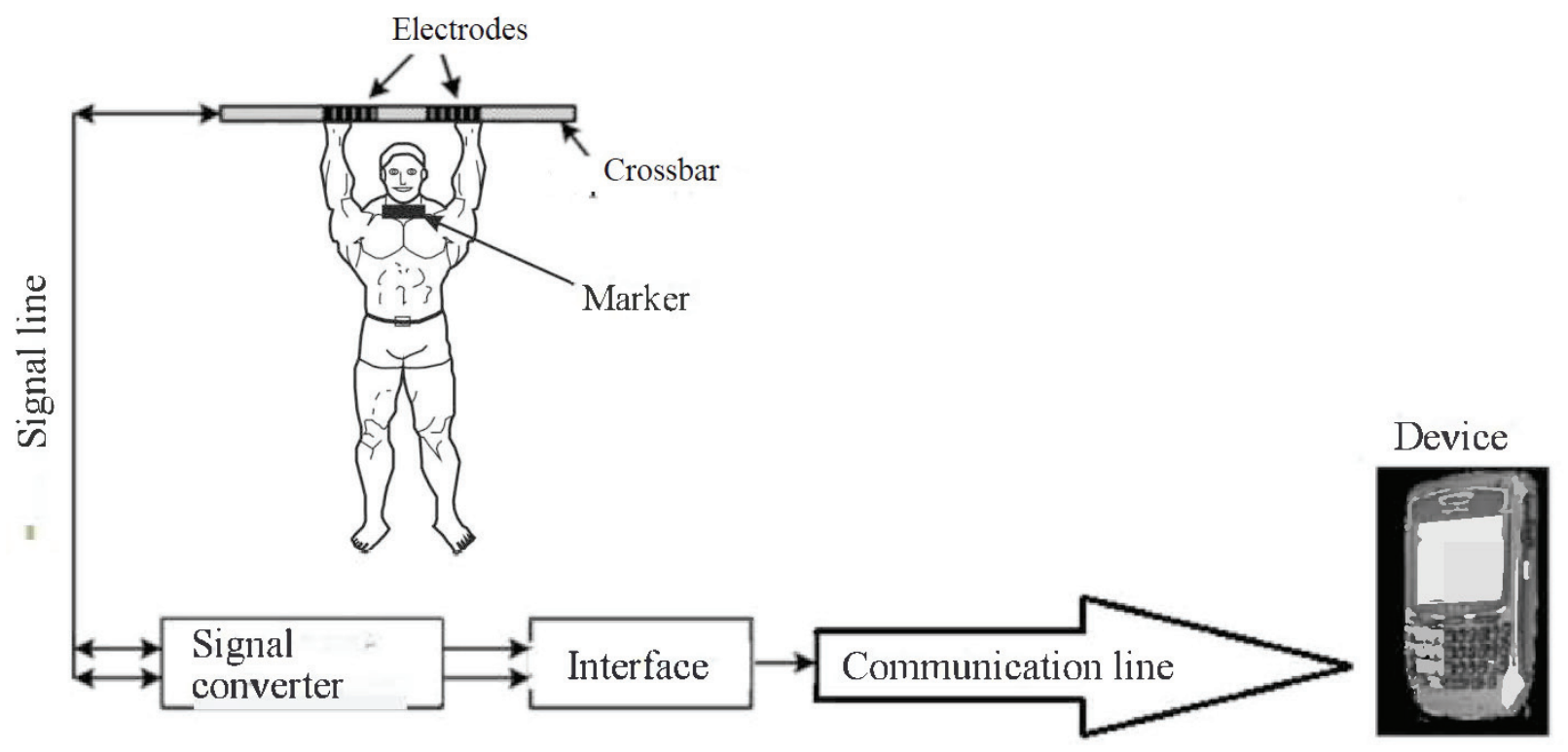

Fig. 1. Block diagram of capacitive sensor testing device

The developed device uses two active capacitive electrodes that place on the crossbar and one passive electrode (marker), which is attached to the collar of the monitoring subject (student).

Nano-fiber «smart textiles» are used to create capacitive electrodes in this device. The latter are made by filling traditional fibrous polymers with nanoparticles of conductive materials, which ensures their high elastic and electrical characteristics (Koryagin \& Blavt, 2019).

In the capacitive sensor testing device, a signal is formed, which is determined by the distance between the active electrodes on the crossbar and the marker. The information from the monitoring entity is transmitted by the set of technical means that make up the data transmission system: signal line, signal converter, interface, communication line.

Active capacitive electrodes are connected to a signal converter by a signal line (a harness of electrical cables), and a passive electrode is contactless, which ensures that there are no cables between this electrode and the signal converter. The signal converter converts the input analog signal into a digital code (digital signal). A feature of digital signal processing is the streaming nature of processing large volumes of data in real time. Data transmission can be digital (stream of binary signals), or by means of digital coding, which provides the switching of the capacitance electrode array to one analog information input and conversion of the type «electrode capacitance - digital code» (Estivalet \& Springer, 2009).

For digital signal processing, the signal converter uses a so-called signal processor. The developed device uses a signal processor of hardware-supported floatingpoint operation. There are several reasons for using floating point signal processing. Working with data in this format significantly simplifies and speeds up processing, increases the reliability of the program, since it does not require operations of rounding and normalization of data, tracking of situations of loss of importance (Alme \& Mylvaganam, 2006).

The digital signal via the interface (in this case USB interface) and the communication line, such as infrared or radio frequency, are then transmitted to the electronic computing device or mobile communication system. Data transmission (digital communication) is the physical transfer of digital stream data in the form of point-to-point or point-to-multipoint signals for further processing by computing equipment, where it is recorded and graphically visualized. The developed software for recording and visualization of the obtained test results is presented in Fig. 2.

Their subsequent archiving takes place in the infrastructure of the centre of data storage and processing in custom-tailored and accessible in text format for each student. Application of software enables simultaneous analysis of test results of a group of students without loss of information.

The proposed method for assessing the endurance of the arms and upper torso is that two active capacitive electrodes are placed on the crossbar and a marker, a passive capacitive electrode with a digital output, is placed on the cell of the monitoring subject (student). An informative signal between the active electrodes on the crossbar and the marker that arises when the position of the monitoring subject (student) changes its position, allows to record the start of the exercise, the process of completion and the end of the exercise. The signal is received by a signal line, transmitted to the signal converter, processed, and wireless infrared communication 


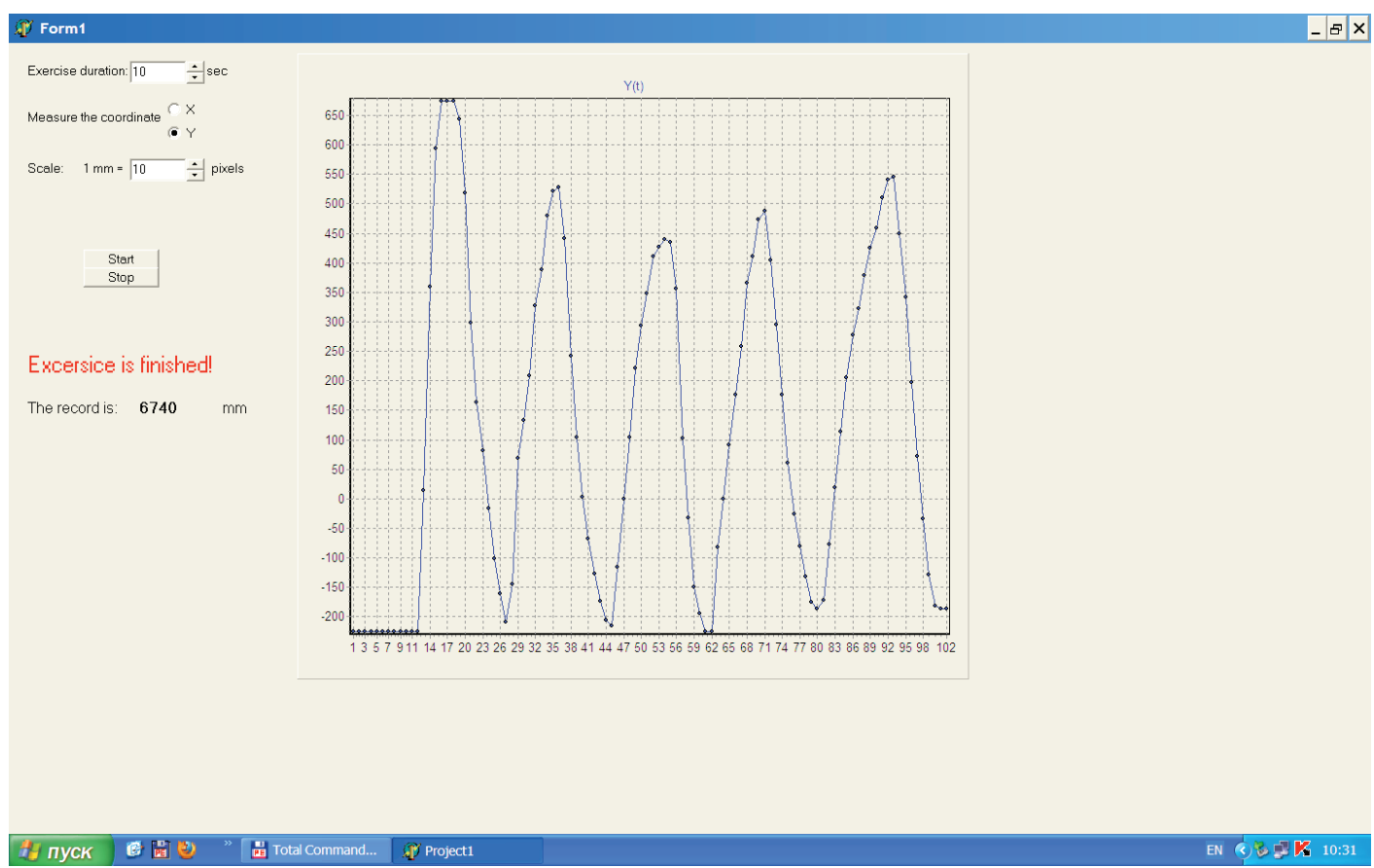

Fig. 2. The developed software for recording and visualization of the obtained test results

devices are fed to an electronic-computing device or mobile telecommunication system, which implements the monitoring of the exercise and the value of which make a conclusion about the strength of endurance students.

Positive features of using our proposed method of testing the endurance of the hands and upper body for students with chronic diseases using ICT means are:

1. ensuring the possibility of conducting an accurate testing procedure;

2. reliability of monitoring;

3. urgent receipt of the result;

4. ease of use and compactness of the device;

5. automatic receipt of multiple test results in the form of an electronic protocol;

6. rapid execution of complex calculations with presentation of results in digital or graphical form;

7. convenient review of the structure of the obtained results and their dynamics.

In general, all of the above makes it possible to ensure that the fitness of students with chronic diseases is objectively monitored.

\section{Discussion}

We support the position that, implementation of the unique possibilities of ICT provides state-of-the-art of didactic method of intensification of control process in physical education of students. The adoption and use of modern ICT in the process of the physical education will help to solve entirely the problems of the current control (Estivalet \& Springer, 2009; Haake, 1996; Prykhodko, 2010). This is in harmony with the contemporary trends in the field. For instance, the Ministry of Education and Science of Ukraine has defined and endorsed the strategic trends of modernization of the system of physical education of youths in educational establishments (Resolution of the Verkhovna Rada of Ukraine).

An objective estimation of a degree of physical development and of physical fitness has special importance during conducting physical education classes with students of the university's (Anikieiev, 2015; Koryahin, Blavt \& Tsiovkh, L. 2018; Shyrobokov, Malinina \& Malinin, 2012).

The results of our study are consistent with a number of scientific developments (Ayers, 2004; Ivashchenko, 2016; Kachan, 2017), one of the promising directions to improve the testing system is the development and practical implementation of new, highly effective means, methods, technologies for integrated control and management of this process.

Our research corroborates the studies (Mac-Duggala et al., 1997; Edwards, 2010; Preatoni, Hamill, Harrison, Hayes, Van Emmerik, Wilson \& Rodano, 2013; Reiman \& Manske, 2009) which postulate that the automation of the process for obtaining and processing information of testing can significantly improve the efficiency of obtaining and evaluating information in real time and significantly reduce time spent on conducting tests.

\section{Conclusions}

The developed infrastructure of the device the testing of strength endurance of hands and upper body provides quick processing of received testing results 
using the methods of multidimensional mathematical analysis. The effectiveness of using the designed device in testing students' of strength endurance of hands and upper body is achieved through the ease of use and compactness of the device, student-friendly testing procedure and the efficiency and reliability of control. The proposed technique of strength endurance testing provides reliable data on the level of general physical fitness of students with chronic diseases of universities in the process of their physical education. The implementation and use of it in practice makes it possible to comprehensively address the issues of current control in the process of physical education. It is a powerful methodological basis for scientifically sound improvement of the educational process of universities in order to increase its effectiveness at the same time.

The introduction and use of modern ICT in the test process in the physical education of students with chronic diseases of universities will allow solving complex issues of current control and its purposeful correction on the basis of an integrated approach to the development of physical qualities.

\section{Conflict of interest}

The authors state no conflict of interest.

\section{References}

Anikieiev, D.M. (2015). Criteria of effectiveness of students' physical education system in higher educational establishments. Physical education of students, 5, 3-8. http:// dx.doi.org/10.15561/20755279.2015.0501

Alme, K.J., \& Mylvaganam, S. (2006). Electrical Capacitance Tomography: Sensor Models, Design, Simulations, and Experimental Verification IEEE. Sensors Journal, 6(5): 1256-1266. https://doi.org/10.1109/JSEN.2006.881409

Ayers, S.F. (2004). High School Students' Physical Education Conceptual Knowledge. Research Quarterly for Exercise and Sport, 75(3), 272-287. https://doi.org/10.1080/0270 1367.2004.10609160

Iedynak, G., Galamandjuk, L., Ivashchenko, V., Stasjuk, I., Guska, M., Prozar, M., Mazur, V., \& Sliusarchuk, V. (2017). Psychosocial aspects of improving physical activity of children with chronic diseases. Journal of Physical Education and Sport, 17(3), 1186-1891. https:// doi.org/10.7752/jpes.2017.03183

Bassett, D.R. (2000). Validity and reliability issues in objective monitoring of physical activity. Research Quarterly for Exercise and Sport, 71, 30-36. https://doi.org/10.10 80/02701367.2000.11082783

Baxter, L.K. (1997). Capacitie sensors: design and application. IEEE Press. 320.

Bracke, W., Puers, R., \& Van Hoof, C. (2007). Ultra low power capacitive sensor interfaces. Springer.

Bykov, V. Yu. (2010). Modern Problems of Informatization of Education. Information Technologies and Learning
Tools, 1(15). Rezhym dostupu:http://www.ime.edu-ua. net/em.html. https://doi.org/10.33407/itlt.v15i1 (in Ukrainian)

Clarys, J.P. \& Cabri, J. (1993). Electromyography and the study of sports movements: A review. Journal of Sports Sciences, 11(5), 379-448. https://doi. org/10.1080/02640419308730010

Capobianco, R.A., Almuklass, A.M. \& Enoka, R.M. (2018). Manipulation of sensory input can improve stretching outcomes. European Journal of Sport Science, 18(1), 83-91. https://doi.org/10.1080/17461391.2017.1394370

Edwards, W.H. (2010). Motor Learning and Control From Theory to Practice. California: Wadsworth.

Estivalet, M., \& Springer, P. (2009). The Engineering of Sport. Paris: Springer-Verlag.

Ivashchenko, O.V. (2016). Pedagogical control of motor and functional fitness of girls 15-16 years. Teorîa $\mathrm{Ta}$ Metodika Fizičnogo Vihovannâ, (3), 36-50. https://doi. org/10.17309/tmfv.2016.3.1171 (in Ukrainian)

Haake, S. (1996). The engineering of sport. Taylor \& Francis.

Hotra, Z., Holyaka, R., Marusenkova, T., \& Potencki, J. (2010). Signal transducers of capacitive microelectronic sensors. Electronika. Rzeszow. Poland, 8, 129-132.

Kachan, O.A. (2017). Implementation of innovative technologies in physical culture and sports activities of educational institutions. Slov'yans 'k: Vy` toky (Slavyansk: Vytoky), 138. (in Ukrainian)

Koryagin, V., \& Blavt, O. (2019). Innovative test control technologies in physical education and sports: a monograph. Lviv, Ukraine: Lviv Polytechnic Publishing House, 236.

Koryahin, V., Mukan, H., Blavt, O., \& Virt, V. (2019). Students' coordination skills testing in physical education: ICT application. Information Technologies and Learning Tools, 70(2), 216-226. https://doi.org/10.33407/itlt.v70i2

Koryahin, V., \& Blavt, O. (2016). Technological provisioning of test control of special health group students' power abilities. Physical education of students, 20(1), 43-48. https://doi.org/10.15561/20755279.2016.0106

Koryahin, V., \& Blavt, O. (2018). The Use of Information and Communication Technology for Determining the Level Mobility in Joint in Physical Education of Students. Teoriâ Ta Metodika Fizičnogo Vihovannâ, 18(3), 107-113. https://doi.org/10.17309/tmfv.2018.3.01

Koryahin, V., Blavt, O., \& Tsiovkh, L. (2018). Regulation of Pedagogical Principles of Control in Physical Education of Students of Special Medical Groups. Teoriâ Ta Metodika Fizičnogo Vihovannâ, 18(1), 3-11. https://doi. org/10.17309/tmfv.2018.1.01(in Ukrainian).

Magill, R.A. (2007). Motor learning and control: Concepts and applications (8th ed.). McGraw-Hill International Edition.

Matiegka, J. (1991). The testing of physical efficiency. Amer Journal of Physical Anthropology, 4(3), 125-134. https:// doi.org/10.1002/ajpa.1330040302

Morze, N. \& Kocharian, A. (2014). ICT competence standards for higher educators and quality assurance in edu- 
cation. Information Technologies and Learning Tools, 5. (in Ukrainian)

Physiological testing of high-class athlete / ed. J. D. MacDuggala [et al.]. (1997). Kiev: Olympic literature. (in Russian).

Preatoni, E., Hamill, J., Harrison, A.J., Hayes, K., Van Emmerik, R., Wilson, C. \& Rodano, R. (2013). Movement variability and skills monitoring in sports. Sports Biomechanics, 12(2), 69-92. https://doi.org/10.1080/14763 141.2012.738700

Prykhodko, V.V. (2010). Innovative Reform of Higher Education in Contemporary Ukraine, Dnipropetrovsk: Porohy. (in Ukrainian)

Reiman, M.P., \& Manske, R.C. (2009). Functional testing in human performance. Champaign IL : Human Kinetics.

Resolution of the Verkhovna Rada of Ukraine "On ensuring the sustainable development of the sphere of physical culture and sports in Ukraine in the conditions of power decentralization" 19.10.2016. 2016. Information from the Verkhovna Rada (VVR), 47, 804. (in Ukrainian).
Stroot, S.A. (2014). Case Studies in Physical Education: Real World Preparation for Teaching. Routledge.

Schmidt, R.A., \& Wrisberg, C.A. (2008). Motor Learning and Performance: A Situation-based Learning Approach. (I. Champaign, Ed.). Human Kinetics.

Sukhova, N. (2009). Quality of higher education as one of the philosophical foundations of education transformation XXI century: the European context. Proceedings of the National Aviation University, 1, 170-174. (in Russian).

Shyrobokov, D., Malinina, Ya. \& Malinin, V. (2012). Features and Disadvantages of Pedagogical Control of Physical Education of Secondary and Higher School Students, Innovations and Modern Technologies in the Education System, 2, 250-252. (in Russian)

Overton, H., Wrench, A., \& Garrett, R. (2016). Pedagogies for inclusion of junior primary students with disabilities in physical education. Physical Education and Sport Pedagogy, 22(4), 414-426. https://doi.org/10.1080/1740 8989.2016.1176134

\title{
ІННОВАЦІЙНА ІНТЕНСИФІКАЦІЯ ТЕСТОВОГО КОНТРОЛЮ СИЛОВОЇ ВИТРИВАЛОСТІ У ФІЗИЧНОМУ ВИХОВАННІ СТУДЕНТІВ 3 ХРОНІЧНІМИ ЗАХВОРЮВАННЯМИ
}

\author{
Корягін В.М., Блавт О.3., Пономарьов С.В. \\ Національний університет «Львівська політехніка» \\ Реферат. Стаття: 7 с., 2 рис., 34 джерела.
}

Мета дослідження - обгрунтування та реалізація сучасних електронних технологічних засобів для вдосконалення тестування силової витривалості рук і верхньої частини тулуба студентів спеціальних медичних груп.

Матеріали та методи. Для вирішення завдань дослідження використано методи порівняння аналізу, синтезу, абстракції, формалізації і технічного моделювання.

Результати. За результатами наукового пошуку, спрямованого на інтеграцію ІКТ в тестовий контроль силової витривалості студентів з хронічними захворюваннями, представлено пристрій сенсорного тестування. Сконструйований ємнісний сенсорний пристрій тестування базується на поєднання сучасних нанотехнологій та мікропро- цесорних систем, зокрема, смартфонів, планшетних комп'ютерів тощо. Конструктивним рішенням пристрою $є$ електронні вимірювальні системи просторового положення об'єктів на базі ємнісних сенсорних пристроїв.

Висновки. Ефективність використання розробленого пристрою для тестування силової витривалості рук і верхньої частини тулуба студентів 3 хронічними захворюваннями досягається за рахунок простоти використання і компактності пристрою, зручної для студентів процедури тестування, а також ефективності і надійності результатів контролю.

Ключові слова: тестування, контроль, студент, хронічні захворювання, IКТ, ємнісний сенсорний пристрій, контроль. 


\title{
ИННОВАЦИОННАЯ ИНТЕНСИФИКАЦИЯ ТЕСТОВОГО КОНТРОЛЯ СИЛОВОЙ ВЫНОСЛИВОСТИ В ФИЗИЧЕСКОМ ВОСПИТАНИИ СТУДЕНТОВ С ХРОНИЧЕСКИМИ ЗАБОЛЕВАНИЯМИ
}

\author{
Корягин В.М., Блавт О.3., Пономарёв С.В. \\ Национальный университет «Львивська политэхника» \\ Реферат. Статья: 7 с., 2 рис., 34 источника.
}

Цель исследования - обоснование и реализация современных электронных технологических средств для совершенствования тестирования силовой выносливости рук и верхней части туловища студентов с хроническими заболеваниями.

Материалы и методы. Для решения задач исследования использовано методы сравнения анализа, синтеза, абстракции, формализации и технического моделирования.

Результаты. По результатам научного поиска, направленного на интеграцию ИКТ в тестовый контроль силовой выносливости студентов с хроническими заболеваниями, представлено устройство сенсорного тестирования. Разработаный емкостный сенсорный прибор тестирования базируется на сочетании современных нанотехнологий и микропроцессорных систем, включая смартфоны, планшеты и т.п. Конструктивным решением устройства являются электронные измерительные системы пространственного положения объектов на базе емкостных сенсорных устройств.

Выводы. Эффективность использования разработанного устройства для тестирования силовой выносливости рук и верхней части туловища студентов с хроническими заболеваниями достигается за счет простоты использования и компактности устройства, удобной для студентов процедуры тестирования, а также эффективности и надежности результатов контроля.

Ключевые слова: тестирование, контроль, студент, хронические заболевания, ИКТ, емкостное сенсорное устройство, контроль.

\section{Information about the authors:}

Koryahin V. M.: koryahinv@meta.ua; orcid.org/0000-0003-1472-4846; National University «Lviv Polytechnic»; Str. Bandera, 12, Lviv, 79013, Ukraine

Blavt O. Z.: oksanablavt@ukr.net; http://orcid.org/0000-0001-5526-9339; National University «Lviv Polytechnic»; Str. Bandera, 12, Lviv, 79013, Ukraine

Ponomaryov S.V.: sponomarov70@gmail.com; https://orcid.org/0000-0002-7953-4317; Lviv Polytechnic National University Str. Bandera, 12, Lviv, 79013, Ukraine

Cite this article as: Koryahin V.M., Blavt O.S., \& Ponomaryov S.V. (2019). Innovative Intestification of Testing of Strength Endurance in Physical Education of Students With Chronic Diseases. Teoriâ ta Metodika Fizičnogo Vihovannâ, 19(3), 116122. https://doi.org/10.17309/tmfv.2019.3.02

Received: 10.08.2019. Accepted: 20.09.2019. Published: 25.09.2019

This work is licensed under a Creative Commons Attribution 4.0 International License (http://creativecommons.org/ licenses/by/4.0). 